\title{
Analisis Kesesuaian Kegiatan Pergudangan dan Pemetaan Proses Pergudangan pada Salah Satu Warehouse Industri Farmasi di Jakarta
}

\author{
Wahyu Ashri Aditya*,1, Ida Musfroh² \\ 1Program Studi Profesi Apoteker, Fakultas Farmasi, Universitas Padjadjaran, \\ 2Departemen Analisis Farmasi dan Kimia Medisinal, Fakultas Farmasi, Universitas Padjadjaran, \\ *E-mail: wahyu15006@unpad.mail.ac.id
}

(Submit 21/4/2020, Revisi 3/5/2020, Diterima 11/5/2020)

\begin{abstract}
Abstrak
Manajemen rantai pasok (Supply Chain Management) pada aspek pergudangan di suatu Industri Farmasi merupakan parameter yang sangat penting dalam suatu rantai distribusi sediaan farmasi; yang terdiri atas penerimaan, penyimpanan hingga pengiriman produk farmasi. Sistem penyimpanan dan pengiriman obat di Industri Farmasi yang baik dan benar mengacu pada Cara Pembuatan Obat yang Baik (CPOB) Tahun 2018 Bab 6 tentang Cara Penyimpanan dan Pengiriman Obat yang Baik. Gudang yang belum menerapkan CPOB akan mengalami kerugian serta kerusakan fisik sediaan farmasi dan juga kerugian finansial akibat produk yang pasif di gudang. Hal ini berdampak kepada penurunan kualitas warehouse dari Industri tersebut. Selain itu, pemetaan proses gudang dilakukan guna melihat dan menghilangkan pemborosan dalam proses kerja agar lead time dapat diperpendek secara signifikan dan kualitas diciptakan dengan benar sejak awal. Maka dari itu, diperlukan adanya evaluasi kegiatan pergudangan dan pemetaan proses pergudangan pada warehouse salah satu Industri Farmasi di Jakarta yang bertujuan untuk melihat kesesuaian kegiatan gudang dengan CPOB dan menghilangkan pemborosan pada gudang. Penelitian dilaksanakan selama bulan Maret 2020 dengan melakukan pengamatan secara observasional dan dilakukan evaluasi. Hasil pengamatan menunjukkan bahwa Industri Farmasi telah memenuhi ketentuan sesuai CPOB akan tetapi masih terdapat beberapa sistem yang memerlukan kesesuaian lebih lanjut dengan $\mathrm{CPOB}$ untuk menghindari waste (pemborosan) dalam proses kerja sehingga diperlukan CAPA untuk evaluasi pada Industri Farmasi tersebut.
\end{abstract}

Kata Kunci: Evaluasi, Pergudangan, Warehouse, Industri Farmasi, CPOB, Waste.

\section{Outline}

- Pendahuluan

- Metode

- Hasil dan Pembahasan

- Kesimpulan

- Daftar Pustaka 


\section{Pendahuluan}

Industri Farmasi merupakah perusahaan yang memiliki fungsi untuk melakukan proses pembuatan atau produksi obat dan/atau bahan obat sesuai dengan ketentuan peraturan perundang-undangan. Semua produk obat tidak cukup apabila hanya lulus pada tiap pengujian yang dilakukan tetapi setiap obat yang diproduksi harus memiliki mutu yang bagus $^{1}$. Agar mutu tiap obat bagus maka diperlukan pedoman agar dapat menjamin kondisi tersebut yaitu pedoman Cara Pembuatan Obat yang Baik (CPOB). CPOB merupakan cara pembuatan obat dan/atau bahan obat yang bertujuan untuk memastikan agar mutu obat dan/atau bahan obat yang dihasilkan sesuai dengan persyaratan dan tujuan penggunaan ${ }^{2}$.

Manajemen rantai pasok merupakan suatu pendekatan agar pemasok, industri atau manufaktur, warehouse (gudang) dan penyimpanan lebih efisien, sehingga barang diproduksi dan disalurkan dalam jumlah, lokasi, dan waktu yang tepat, agar dapat meminimalisir biaya dan memberikan kepuasan layanan kepada pelanggan ${ }^{3}$. Manajemen rantai pasok obat memiliki aspek penting dalam pelaksanaannya, yaitu aspek penyimpanan dan pengiriman. Tata cara mengenai penyimpanan dan pengiriman sediaan farmasi yang baik dan benar pada Industri Farmasi diatur dalam Pedoman CPOB Bab 6 Cara Penyimpanan dan Pengiriman Obat yang Baik. Mutu obat pada warehouse dapat dipengaruhi ketika kurangnya pengendalian terhadap proses penerimaan, penyimpanaan hingga penyaluran atau pengiriman obat. Pedoman CPOB ini dapat membantu untuk menjamin mutu obat selama proses penerimaan, penyimpanaan hingga penyaluran atau pengiriman obat. Apabila warehouse di Industri Farmasi tersebut juga sebagai pusat distribusi yang dapat melakukan penyaluran ke fasilitas distribusi maupun pelayanan secara langsung maka harus menerapkan pedoman $\mathrm{CDOB}^{2}$. Pengelolaan perbekalan farmasi di Industri Farmasi dilaksanakan oleh bagian SCM (Supply Chain Management) atau PPIC (Production Planning and Inventory Control) khususnya bagian warehouse (gudang). Agar tercapai tingkat efektifitas dan efisiensi dalam pengelolaan perbekalan farmasi, sangatlah dibutuhkan manajemen logistik yang baik.

Warehouse merupakan sarana pendukung untuk kegiatan produksi pada industri farmasi yang berfungsi untuk menyimpan bahan baku atau bahan awal, bahan pengemas, dan obat jadi yang belum disalurkan. Fungsi lain gudang juga untuk melindungi material dan obat jadi ${ }^{4}$. Warehouse mempunyai fungsi penting dalam menjaga mutu obat jadi sampai disalurkan ke konsumen. Setiap aktivitas yang dilakukan pada warehouse atau gudang sangatlah penting sehingga Industri Farmasi perlu meningkatkan performa secara terus menerus agar selalu efektif dan efisien dan selalu mempertahankan kepercayaan kustomer dan meningkatkan mutu perusahaan ${ }^{5}$. Aktivitas dalam gudang yang merupakan parameter kritis dalam rantai pasok yang akan menentukan kelancaran alur distribusi dari supplier ke pelanggan adalah aspek penyimpanan dan pengiriman ${ }^{6}$. Berbagai faktor yang mempengaruhi penyimpanan seperti metode pengambilan pesanan, ukuran dan tata letak sistem penyimpanan, sistem penanganan material, karakteristik produk, tren permintaan, tingkat turnover dan persyaratan ruang telah dipelajari secara luas ${ }^{7}$. 
Masalah yang terjadi dalam faktor fasilitas penyimpanan adalah kapasitas fasilitas penyimpanan yang masih mengalami kejadian overload di industri farmasi tertentu ${ }^{8}$. Ketidakefektifan dan efisiennya warehouse dalam mengelola obat dapat dilihat melalui adanya pemborosan atau waste pada proses pergudangan. Waste merupakan aktivitas-aktivitas yang tidak memberikan nilai tambah bagi perusahaan sehingga perlu ditiadakan agar proses pada warehouse berjalan lancar. Untuk menghilangkan pemborosan, tiap perusahaan manufaktur perlu melakukan perubahan sistem, menggunakan konsep Lean Manufacturing.

Lean Manufacturing merupakan suatu metode untuk memproduksi produk yang dapat menghilangkan pemborosan yang ditemukan pada proses pemetaan dan penerapan flow (aliran), sebagai ganti batch dan antrian ${ }^{9,10}$. Konsep Lean Manufacturing memberikan suatu metode ataupun alat untuk peningkatakan efisiensi pada bidang manufaktur. Internal benchmarking direkomendasikan agar lebih efisiensi dan dapat melihat perbaikan bidang manufaktur khususnya industri farmasi ${ }^{11}$. Penerapan Lean Manufacturing dapat mengurangi serta menghilangkan waste seperti, menekan waktu atau leadtime produksi, aktivitas-aktivitas yang tidak dibutuhkan, biaya produksi dan masih banyak lainnya ${ }^{12,13}$. Pada penelitian Harsono (2010) pada penerapan konsep lean memberikan hasil pengurangan lead time produksi, dimana awalnya 5622.2 menit, kemudian setelah menerapkan konsep lean maka lead time menjadi 4331.2 menit $^{14}$.

Oleh karena pentingnya penerapan $\mathrm{CPOB}$ pada industri farmasi khususnya pada warehouse, maka perlu dilakukan evaluasi kesesuaian kegiatan pergudangan dan pemetaan proses pergudangan pada salah satu gudang Industri Farmasi di Jakarta dalam rangka memastikan kesesuaian dengan CPOB.

\section{Metode}

Penelitian dilaksanakan selama bulan Maret 2020 di salah satu Industri Farmasi di Jakarta. Penelitian dilakukan dengan melakukan pengamatan secara observasional dengan menganalisis kesesuaian dengan CPOB 2018 Bab 6 tentang Cara Penyimpanan dan Pengiriman Obat yang Baik dan pemetaan proses pergudangan. Kemudian dilakukan evaluasi dengan metode CAPA (Corrective Action and Preventif Action). Wawancara kepada warehouse supervisor dilakukan untuk mengonfirmasi sistem yang diobservasi.

\section{Hasil dan Pembahasan}

\section{Evaluasi Sistem Kegiatan Pergudangan}

Mutu awal obat dapat dijaga dengan melaksanakan kegiatan pergudangan seperti penyimpanan dan pengirimannya sesuai pedoman CPOB. Gudang Industri Farmasi yang diteliti tidak bertindak sebagai pusat distribusi produk sehingga tidak perlu menerapkan pedoman CDOB. 
Tabel 1. Hasil Analisis Kesesuaian Kegiatan Pergudangan dengan CPOB 2018 Bab VI

\begin{tabular}{|c|c|c|}
\hline NO & ASPEK DETAIL & $\begin{array}{l}\text { KESIMPULAN } \\
\text { (SESUAITIDAK } \\
\text { SESUAI) }\end{array}$ \\
\hline 1 & PERSONALIA & \\
\hline 1.1 & $\begin{array}{l}\text { Apakah personil pernah mengikuti pelatihan yang sesuai dengan tanggung } \\
\text { jawabnya khususnya personil kunci? }\end{array}$ & Sesuai \\
\hline$\overline{1.2}$ & Apakah tersedia SOP yang mengatur akses personil terhadap area gudang? & Sesuai \\
\hline 1.3 & $\begin{array}{l}\text { Apakah memiliki program pelatihan personel yang mencakup identifikasi } \\
\text { kebutuhan pelatihan dan rencana pelaksanaanya? }\end{array}$ & Sesuai \\
\hline 2 & ORGANISASI DAN MANAJEMEN & \\
\hline 2.1 & $\begin{array}{l}\text { Apakah tersedia struktur organisasi mencakup tanggung jawab, kewenangan } \\
\text { dan hubungan timbal-balik semua personel yang disyaratkan dalam CPOB? }\end{array}$ & Sesuai \\
\hline$\overline{2.2}$ & $\begin{array}{l}\text { Apakah semua personel memahami peran dan tanggungjawab dalam } \\
\text { organisasi terkait penerapan CPOB? }\end{array}$ & Sesuai \\
\hline 2.3 & $\begin{array}{l}\text { Apakah tersedia sistem keselamatan yang berkaitan dengan semua } \\
\text { aspek yang relevan? }\end{array}$ & Sesuai \\
\hline 3 & MANAJEMEN MUTU & \\
\hline 3.1 & $\begin{array}{l}\text { Apakah pada transaksi secara elektronis, tersedia sistem yang memadai dan } \\
\text { prosedur yang jelas untuk menjamin ketertelusuran dan kepastian mutu obat? }\end{array}$ & Sesuai \\
\hline 3.2 & $\begin{array}{l}\text { Apakah tersedia SOP pelulusan obat yang disetujui untuk memastikan bahwa } \\
\text { obat dijual dan didistribusikan hanya kepada distributor dan/atau sarana yang } \\
\text { berwenang? }\end{array}$ & Sesuai \\
\hline 3.3 & Apakah tersedia SOP untuk memastikan ketertelusuran distribusi produk? & Sesuai \\
\hline$\overline{4 .}$ & BANGUNAN DAN FASILITAS PENYIMPANAN & \\
\hline 4.1 & Area Penyimpanan & \\
\hline 4.1 .1 & $\begin{array}{l}\text { Apakah obat disimpan dengan cara yang sesuai untuk mencegah } \\
\text { kontaminasi, kecampurbauran dan kontaminasi silang? }\end{array}$ & Sesuai \\
\hline 4.1 .2 & $\begin{array}{l}\text { Apakah area penyimpanan diberikan pencahayaan yang memadai } \\
\text { sehingga semua kegiatan dapat dilakukan secara akurat dan aman? }\end{array}$ & Tidak Sesuai \\
\hline 4.1 .3 & $\begin{array}{l}\text { Apakah sarana pengaman untuk mencegah binatang pengerat, burung dan } \\
\text { serangga masuk memadai? }\end{array}$ & Sesuai \\
\hline 4.1 .4 & $\begin{array}{l}\text { Apakah tersedia palet atau peralatan lain yang menjamin obat dan/atau } \\
\text { bahan obat tidak bersentuhan langsung dengan lantai? }\end{array}$ & Sesuai \\
\hline 4.1 .5 & Apakah luas ruang penyimpanan memadai & Tidak Sesuai \\
\hline 4.2 & Rotasi dan Pengendalian Stok & \\
\hline$\overline{4.2 .1}$ & $\begin{array}{l}\text { Apakah rekonsiliasi stok secara berkala dengan membandingkan jumlah } \\
\text { persediaan (stok) sebenarnya dengan yang tercatat? }\end{array}$ & Sesuai \\
\hline$\overline{4.2 .2}$ & $\begin{array}{l}\text { Apakah perbedaan stok diinvestigasi untuk memastikan bahwa tidak ada } \\
\text { kecampur-bauran karena kelalaian, kesalahan pengeluaran dan/atau } \\
\text { penyalahgunaan obat? }\end{array}$ & Sesuai \\
\hline$\overline{5}$ & PENERIMAAN & \\
\hline$\overline{5.1}$ & $\begin{array}{l}\text { Apakah dilakukan pemeriksaan jumlah produk pada saat penerimaan untuk } \\
\text { memastikan jumlah yang diterima sesuai dengan jumlah yang tercantum } \\
\text { dalam catatan penyerahan dari produksi? }\end{array}$ & Sesuai \\
\hline 5.2 & $\begin{array}{l}\text { Apakah obat yang membutuhkan penyimpanan khusus (misal: narkotik, } \\
\text { psikotropik, prekursor dan produk dengan suhu penyimpanan tertentu) } \\
\text { diidentifikasi dan ditempatkan sesuai prosedur tertulis? }\end{array}$ & Sesuai \\
\hline 5.3 & Apakah ada SOP penerimaan produk dari bagian produksi? & Sesuai \\
\hline 5.4 & Apakah ada SOP penerimaan bahan awal dan bahan pengemas? & Sesuai \\
\hline$\overline{5.5}$ & $\begin{array}{l}\text { Apakah ada sistem untuk mencegah penerimaan bahan dari pemasok yang } \\
\text { belum disetujui? }\end{array}$ & Sesuai \\
\hline
\end{tabular}




\begin{tabular}{|c|c|c|}
\hline NO & ASPEK DETAIL & $\begin{array}{l}\text { KESIMPULAN } \\
\text { (SESUAITIDAK } \\
\text { SESUAI) }\end{array}$ \\
\hline 5.6 & Apakah ada daftar periksa penerimaan bahan? & Sesuai \\
\hline 5.7 & Apakah wadah dibersihkan sebelum dimasukkan ke dalam karantina? & Sesuai \\
\hline$\underline{\underline{6}}$ & KONDISI PENYIMPANAN DAN TRANSPORTASI & \\
\hline 6.1 & Pemantauan Kondisi Penyimpanan dan Transportasi & \\
\hline 6.1 .1 & $\begin{array}{l}\text { Apakah kondisi penyimpanan dan pengangkutan yang sesuai diinformasikan } \\
\text { kepada pihak yang bertanggung jawab atas transportasi obat? }\end{array}$ & Sesuai \\
\hline 6.1 .2 & Apakah tersedia catatan pemantauan suhu penyimpanan tiap gudang? & Sesuai \\
\hline 6.1 .3 & Apakah tersedia SOP penyimpanan dan pengiriman obat? & Sesuai \\
\hline 6.1 .4 & $\begin{array}{l}\text { Apakah tersedia SOP penanganan terhadap penyimpangan persyaratan } \\
\text { penyimpanan? }\end{array}$ & Sesuai \\
\hline 6.1 .5 & Apakah mempunyai sistem yang menjamin first in first out / first exp first out? & Sesuai \\
\hline 6.1 .6 & Apakah label dan brosur disimpan dalam lemari terkunci? & Sesuai \\
\hline 6.1 .7 & $\begin{array}{l}\text { Apakah suhu dan kelembaban udara di ruang penyimpanan dimonitor sesuai } \\
\text { dengan yang dipersyaratkan masing-masing produk menggunakan alat ukur } \\
\text { yang terkalibrasi? }\end{array}$ & Sesuai \\
\hline 6.2 & Kendaraan dan Perlengkapan & \\
\hline 6.2 .1 & $\begin{array}{l}\text { Apakah kendaraan dan perlengkapan dapat mencegah pemaparan produk } \\
\text { terhadap kondisi yang dapat memengaruhi stabilitas produk dan keutuhan } \\
\text { kemasan, serta mencegah semua jenis kontaminasi? }\end{array}$ & Sesuai \\
\hline 6.2 .2 & $\begin{array}{l}\text { Apakah menggunakan kendaraan dan perlengkapan tersendiri untuk } \\
\text { menangani obat? }\end{array}$ & Tidak Sesuai \\
\hline 6.2 .3 & $\begin{array}{l}\text { Apakah alat untuk memantau kondisi di dalam kendaraan dan wadah } \\
\text { pengiriman dilakukan kalibrasi secara berkala? }\end{array}$ & Sesuai \\
\hline 6.2 .4 & $\begin{array}{l}\text { Apakah kendaraan dan wadah pengiriman mempunyai kapasitas yang } \\
\text { memadai untuk penempatan secara teratur berbagai kategori obat selama } \\
\text { transportasi? }\end{array}$ & Sesuai \\
\hline 6.2 .5 & $\begin{array}{l}\text { Apakah tersedia tindakan pengamanan untuk mencegah pihak yang tidak } \\
\text { berwenang masuk dan/atau merusak kendaraan dan/atau perlengkapan, } \\
\text { serta mencegah pencurian atau penggelapan? }\end{array}$ & Sesuai \\
\hline 6.3 & Wadah Pengiriman dan Pelabelan & \\
\hline 6.3 .1 & $\begin{array}{l}\text { Apakah obat disimpan dan dikirimkan dalam wadah pengiriman yang tidak } \\
\text { mengakibatkan efek merugikan terhadap mutu produk, dan memberikan } \\
\text { perlindungan yang memadai terhadap pengaruh eksternal, termasuk } \\
\text { kontaminasi? }\end{array}$ & Sesuai \\
\hline 6.3 .2 & $\begin{array}{l}\text { Apakah pada label wadah pengiriman mencantumkan informasi yang } \\
\text { memadai mengenai kondisi penanganan dan penyimpanan serta tindakan } \\
\text { yang diperlukan untuk menjamin penanganan yang tepat? }\end{array}$ & Sesuai \\
\hline 6.3 .3 & $\begin{array}{l}\text { Apakah tersedia SOP penanganan wadah pengiriman yang rusak dan/atau } \\
\text { pecah? }\end{array}$ & Sesuai \\
\hline 6.4 & Pengiriman & \\
\hline 6.4 .1 & $\begin{array}{l}\text { Apakah setiap pengiriman obat berdasarkan permintaan pesanan resmi atau } \\
\text { rencana penggantian produk yang resmi dan didokumentasikan? }\end{array}$ & Sesuai \\
\hline 6.4 .2 & $\begin{array}{l}\text { Apakah catatan pengiriman berisi informasi yang cukup untuk menjamin } \\
\text { ketertelusuran dan mempermudah penarikan obat? }\end{array}$ & Sesuai \\
\hline 6.4 .3 & $\begin{array}{l}\text { Apakah dilakukan validasi pengiriman untuk membuktikan bahwa seluruh } \\
\text { kondisi penyimpanan terpenuhi pada seluruh rantai distribusi }\end{array}$ & Sesuai \\
\hline$\overline{6.4 .4}$ & $\begin{array}{l}\text { Apakah tersedia sistem untuk mencegah pengiriman obat yang telah } \\
\text { kedaluwarsa, atau mendekati tanggal kedaluwarsa? }\end{array}$ & Sesuai \\
\hline
\end{tabular}




\begin{tabular}{|c|c|c|}
\hline NO & ASPEK DETAIL & $\begin{array}{l}\text { KESIMPULAN } \\
\text { (SESUAITIDAK } \\
\text { SESUAI) }\end{array}$ \\
\hline 7 & DOKUMENTASI & \\
\hline$\overline{7.1}$ & Apakah memiliki SOP Dokumentasi? & Sesuai \\
\hline 7.2 & $\begin{array}{l}\text { Apakah mempunyai sistem untuk melakukan transfer informasi, baik } \\
\text { informasi mengenai mutu atau regulasi antara industri farmasi dan pelanggan } \\
\text { maupun transfer informasi kepada Badan POM sesuai persyaratan? }\end{array}$ & Sesuai \\
\hline$\overline{7.3}$ & $\begin{array}{l}\text { Apakah sistem dokumentasi manual atau elektronik sesuai dengan ketentuan } \\
\text { serta dapat ditelusuri setiap saat? }\end{array}$ & Sesuai \\
\hline$\overline{7.4}$ & $\begin{array}{l}\text { Apakah tersedia catatan permanen, baik tertulis maupun elektronis, untuk } \\
\text { tiap produk yang disimpan yang mengindikasikan kondisi penyimpanan yang } \\
\text { direkomendasikan? }\end{array}$ & Sesuai \\
\hline 7.5 & Apakah tersedia tersedia backup untuk mencegah kehilangan data? & Sesuai \\
\hline 8 & KELUHAN & \\
\hline 8.1 & $\begin{array}{l}\text { Apakah semua keluhan dan informasi lain tentang kemungkinan kerusakan } \\
\text { dan kemungkinan pemalsuan obat dilakukan kajian dengan seksama sesuai } \\
\text { SOP mengenai tindakan yang perlu dilakukan, termasuk tindakan penarikan } \\
\text { obat jika diperlukan? }\end{array}$ & Sesuai \\
\hline 9 & PRODUK KEMBALIAN & \\
\hline 9.1 & Apakah tersedia SOP Produk Kembalian? & Sesuai \\
\hline 9.2 & $\begin{array}{l}\text { Apakah obat dan/atau bahan obat kembalian yang diterima karena tidak } \\
\text { memenuhi syarat mutu dan yang mengalami kerusakan penandaan, } \\
\text { dikarantina dan terkunci? }\end{array}$ & Sesuai \\
\hline 9.3 & $\begin{array}{l}\text { Apakah penanganan Produk Kembalian dilakukan sesuai SOP dengan benar } \\
\text { dan didokumentasikan }\end{array}$ & Sesuai \\
\hline 10 & KEGIATAN KONTRAK & \\
\hline 10.1 & $\begin{array}{l}\text { Apakah setiap kegiatan yang terkait dengan penyimpanan dan pengiriman } \\
\text { obat yang didelegasikan kepada orang atau sarana lain dilengkapi dengan } \\
\text { perjanjian kerjasama yang sesuai ketentuan? }\end{array}$ & Sesuai \\
\hline 10.2 & $\begin{array}{l}\text { Apakah didalam kontrak menegaskan tanggung jawab masing-masing pihak, } \\
\text { termasuk ketaatan terhadap prinsip-prinsip CDOB }\end{array}$ & Sesuai \\
\hline 10.3 & Apakah penerima kontrak diaudit secara berkala? & Sesuai \\
\hline
\end{tabular}

Berikut observasi dan evaluasi CPOB pada salah satu Industri Farmasi:

\section{Personalia}

Pada aspek personalia, Industri Farmasi tersebut telah memenuhi kriteria CPOB. Personil yang berhubungan pada aktivitas penyimpanan dan pengiriman produk pada warehouse telah mengikuti pelatihan sesuai dengan tanggung jawab masing - masing. Tiap personil telah memiliki jadwal pelatihan khusus sesuai tanggung jawab dan kebutuhan khusus personil tersebut. Program pelatihan tersebut telah dibuat untuk 1 tahun kedepan dimana mencakup kebutuhan pelatihan masing masing personil. Selain itu, sudah memilihi prosedur untuk memasuki akses gudang untuk menghindari personil yang tidak berwenang memasuki area gudang dan mengisi buku akses masuk gudang ${ }^{2,15}$.

\section{Organisasi dan Manajemen}

Bagian warehouse atau gudang sudah memiliki struktur organisasi yang mencakup tanggung jawab, kewenangan dan uraian tugas masing masing personil. 
Tiap personil harus mendapatkan tanggung jawab yang sesuai dengan porsi masing masing dan tidak boleh berlebihan karena hal tersebut dapat berakibat pada kelelahan atau cedera pada personil yang mengurangi kualitas kerja personil tersebut yang juga akan berakibat pada mutu produk. Pada Industri Farmasi tersebut sudah memiliki prosedur tetap (protap) keselamatan tiap personil pada semua aspek².

Tabel 2. Hasil Corrective Action Preventive Action (CAPA) dari Hasil Temuan

\begin{tabular}{|c|c|c|c|c|}
\hline $\begin{array}{l}\text { Aspek CPOB } \\
2018 \text { BAB } 6\end{array}$ & Temuan & Persyaratan & $\begin{array}{l}\text { Root Cause } \\
\text { Analysis }\end{array}$ & $\begin{array}{l}\text { Tindakan Perbaikan / } \\
\text { Tindakan Pencegahan }\end{array}$ \\
\hline $\begin{array}{c}\text { Bangunan dan } \\
\text { Fasilitas } \\
\text { Penyimpanan }\end{array}$ & $\begin{array}{c}\text { Area } \\
\text { penyimpanan } \\
\text { tidak diberikan } \\
\text { pencahayaan yang } \\
\text { memadai }\end{array}$ & $\begin{array}{c}\text { Area } \\
\text { penyimpanan } \\
\text { diberikan } \\
\text { pencahayaan } \\
\text { yang memadai }\end{array}$ & $\begin{array}{c}\text { Kurangnya } \\
\text { pencahayaan pada } \\
\text { penyimpanan } \\
\text { bahan pengemas }\end{array}$ & $\begin{array}{l}\text { Melakukan penambahan } \\
\text { pencahayaan pada ruang } \\
\text { penyimpanan agar } \\
\text { mencegah kesalahan } \\
\text { pengambilan produk. }\end{array}$ \\
\hline $\begin{array}{l}\text { Bangunan dan } \\
\text { Fasilitas } \\
\text { Penyimpanan }\end{array}$ & $\begin{array}{l}\text { Luas ruang } \\
\text { penyimpanan } \\
\text { tidak memadai }\end{array}$ & $\begin{array}{l}\text { Luas ruang } \\
\text { penyimpanan } \\
\text { harus memadai } \\
\text { untuk semua } \\
\text { barang }\end{array}$ & $\begin{array}{l}\text { Adanya over } \\
\text { production dan } \\
\text { barang pasif di } \\
\text { warehouse }\end{array}$ & $\begin{array}{l}\text { Melakukan perencanaan } \\
\text { pembelian yang lebih akurat } \\
\text { dan terjadwal dengan baik } \\
\text { serta segera mengatasi } \\
\text { barang pasif. }\end{array}$ \\
\hline $\begin{array}{c}\text { Kondisi } \\
\text { Penyimpanan } \\
\text { dan } \\
\text { Transportasi }\end{array}$ & $\begin{array}{l}\text { Tidak tersedia SOP } \\
\text { penanganan } \\
\text { terhadap } \\
\text { penyimpangan } \\
\text { persyaratan } \\
\text { penyimpanan }\end{array}$ & $\begin{array}{l}\text { Tersedia SOP } \\
\text { penanganan } \\
\text { terhadap } \\
\text { penyimpangan } \\
\text { persyaratan } \\
\text { penyimpanan }\end{array}$ & $\begin{array}{l}\text { Departemen lain } \\
\text { sudah membuat } \\
\text { SOP tersebut } \\
\text { sehingga } \\
\text { departemen WH } \\
\text { tidak memiliki }\end{array}$ & $\begin{array}{l}\text { Dibuat SOP penanganan } \\
\text { terhadap penyimpangan } \\
\text { persyaratan penyimpanan } \\
\text { dan sosialisasi dengan cara } \\
\text { memberikan pelatihan. }\end{array}$ \\
\hline $\begin{array}{c}\text { Kondisi } \\
\text { Penyimpanan } \\
\text { dan } \\
\text { Transportasi }\end{array}$ & $\begin{array}{l}\text { Tidak } \\
\text { menggunakan } \\
\text { kendaraan dan } \\
\text { perlengkapan } \\
\text { tersendiri untuk } \\
\text { menangani obat }\end{array}$ & $\begin{array}{l}\text { Menggunakan } \\
\text { kendaraan dan } \\
\text { perlengkapan } \\
\text { tersendiri untuk } \\
\text { menangani obat }\end{array}$ & $\begin{array}{c}\text { Pernah } \\
\text { menggunakan } \\
\text { kendaraan sendiri } \\
\text { tetapi terdapat } \\
\text { pengeluaran yang } \\
\text { lebih banyak }\end{array}$ & $\begin{array}{l}\text { Dianjurkan menggunakan } \\
\text { kendaraan pribadi, kalau } \\
\text { tidak menggunakan harus } \\
\text { dipantau pada setiap } \\
\text { distribusi. }\end{array}$ \\
\hline
\end{tabular}

\section{Manajemen Mutu}

Pada transaksi elektronik yang dilakukan pada Industri Farmasi tersebut, telah tersedia sistem dan protap agar dapat terjamin mutu dan ketertelusuran obat dimana telah dilakukan validasi komputerisasi terlebih dahulu terhadap sistem transaksi elektronik. Pada saat pengiriman produk ke distributor, dilihat terlebih dahulu obat tersebut telah memenuhi persyaratan dan dikirim ke distributor yang berwenang dengan melihat daftar distributor yang telah disetujui oleh Industri Farmasi tersebut serta dapat ditelusuri ketertelusuran produk dimana dilakukan dengan penelusuran secara berkala menggunakan GPS $^{2,15}$.

\section{Bangunan dan Fasilitas Penyimpanan}

\section{Area Penyimpanan}

Setiap obat memiliki ruang penyimpanan masing masing sesuai jenis dan kondisi penyimpanan produk tersebut yang berfungsi untuk mencegah kontaminasi dan ketercampurbauran produk serta menjaga kualitas produk tersebut. 
Industri Farmasi tersebut memilihi area penyimpanan untuk bahan baku baik suhu ruang atau suhu dingin, bahan pengemas, produk jadi baik pada suhu ruang, suhu sejuk atau suhu dingin untuk produk CCP (Cold Chain Product). Indonesia adalah benua yang luas dengan suhu dan suhu yang berbeda kondisi lingkungan bervariasi 25 hingga diatas $30^{\circ} \mathrm{C}$ di tempat yang berbeda. Hal tersebut menjadi tantangan yang berbeda untuk obat produsen agar dapat memastikan obat dipertahankan pada persyaratan suhu sepanjang siklus hidup mereka. Masalah suhu logistik yang terkontrol adalah salah satu masalah yang patut dicatat. Kegagalan untuk mempertahankan obat pada suhu yang ditentukan sering mengakibatkan hilangnya kemanjuran ${ }^{16}$. Setiap produk yang disimpan diletakkan di atas pallet agar mencegah produk tidak bersentuhan langsung dengan lantai. Selain itu, pada titik tertentu area penyimpanan telah tersedia alat pengontrol hama agar mencegah binatang masuk ke area penyimpanan².

Terdapat ketidaksesuaian aspek ini pada Industri Farmasi tersebut dimana pada area penyimpanan khususnya pada area suhu kamar untuk penyimpanan bahan pengemas kurang adanya pencahayaan yang dapat menyebabkan kegiatan yang dilakukan pada area tersebut tidak optimal yang akan menyebabkan terjadinya kesalahan pada saat pengambilan barang yang tidak akurat dan dapat menyebabkan kecelakaan. Hal ini terjadi dikarenakan produk yang disimpan di rak paling atas menutupi pencahayaan sehingga produk yang di bawah tertutupi dan mengurangi pencahayaan pada area lain. Pada CPOB dijelaskan bahwa setiap area penyimpanan harus mendapatkan pencahayaan yang memadai agar kegiatan akurat dan aman. Rekomendasi cahaya untuk area gudang dari CPOB sekitar 200 Lux. Untuk mengatasi hal tersebut, perlu ditambahkan pencahayaan agar dapat mencegah kesalahan dan kecelakaan pada area tersebut serta menyimpan produk di rak paling atas ke tempat lain yang tidak menghalangi pencahayaan pada area tersebut ${ }^{17}$.

Selain pencahayaan yang kurang, kapasitas penyimpanan pada gudang Industri Farmasi tersebut kurang memadai yang ditandai dengan adanya penyimpanan barang di luar rak atau tidak sesuai penyimpanannya yang mengakibatkan berkurangnya akses jalan untuk melakukan pengambilan dan penyimpanan barang. Hal tersebut disebabkan karena kurangnya rak penyimpanan dan masih adanya barang pasif yang telah lama disimpan dan tidak digunakan sehingga dibiarkan menumpuk yang menyebabkan barang yang baru datang atau diproduksi diletakkan tidak sesuai area penyimpanan. Gudang yang baik harus mengosongkan rak penyimpanan sebanyak $30 \%$ agar dapat menghindari banyaknya pesanan dari pelanggan. Industri Farmasi tersebut harus menambah rak penyimpanan atau menyimpan pada gudang atau sarana lain dengan kontrak tertentu agar penyimpanan mencukupi dan kualitas produk terus terjaga.

\section{Rotasi dan Pengendalian Stok}

Untuk menyesuaikan stok pada gudang secara fisik dan sistem, Industri Farmasi melakukan Stock Opname setahun sekali dan Cylce Count untuk memastikan tidak adanya perbedaan secara fisik dan sistem. Selain itu, berguna untuk memantau transaksi yang sedang berjalan agar tidak ada transaksi yang mencurigakan. 
Apabila terdapat perbedaan stok antara fisik dan sistem langsung dilaporkan kepada petugas yang berwenang dan diinvestigasi serta dilakukan evaluasi agar dapat mencegah hal tersebut terulang kembali².

\section{Penerimaan}

Penerimaan dilakukan untuk produk lokal dan import. Pada Industri Farmasi tersebut telah dilakukan aturan untuk unloading barang maksimal dilakukan selama 3 jam agar mengurangi dampak produk diluar kondisi penyimpanan. Setiap melakukan penerimaan, dilakukan pemeriksaan jumlah produk dan identitas produk yang diterima agar menjamin kebenaran sesuai dengan yang di pesan. Apabila produk lokal mengalami kecacatan maka langsung ditolak dan dikembalikan, sebaliknya untuk produk import tetap diterima akan tetapi diuji terlebih dahulu apakah bisa digunakan atau tidak. Untuk produk yang membutuhkan penyimpanan khusus seperti suhu tertentu akan dilihat terlebih dahulu suhu penerimaan apakah sesuai atau tidak².

\section{Kondisi Penyimpanan}

\section{Pemantauan Kondisi Penyimpanan dan Transportasi}

Bagian warehouse selalu memberitahukan setiap kondisi penyimpanan dan pengiriman kepada pihak ke 3 yang melakukan pengiriman ke pihak distributor, agar setiap produk dapat terjaga mutunya pada tiap tahap rantai pasok. Pada kondisi penyimpanan di warehouse Industri Farmasi tersebut juga selalu dijaga dengan selalu mengecek suhu pada tiap titik ruangan penyimpanan dan selalu dicatat setiap harinya pada catatan pemantauan suhu yang dilakukan tiap siang hari dan khusus untuk ruang pendingin dengan suhu $2-8{ }^{\circ} \mathrm{C}$ dicek tiap pagi dan siang hari. Ketika terjadi penyimpangan persyaratan seperti penyimpangan suhu, dilakukan investigasi oleh Departemen yang bertanggung jawab dan diberi keputusan apakah produk tersebut bisa digunakan atau harus dimusnahkan².

Industri Farmasi tersebut memiliki 4 kategori penyimpanan:

1. Ruangan ber- $A C: \leq 25^{\circ} \mathrm{C}$ adalah Ruangan untuk menyimpan bahan baku dan bahan pengemas yang sensitif terhadap panas serta obat jadi.

2. Ruang pendingin ( $\mathrm{Coo} / \mathrm{store}): 12^{\circ} \mathrm{C}-16^{\circ} \mathrm{C}$ adalah ruang untuk menyimpan bahan baku atau obat jadi yang perlu disimpan di cool store.

3. Ruang suhu ambient / kamar: $\leq 30^{\circ} \mathrm{C}$ adalah ruang untuk menyimpan bahan pengemas, bahan baku dan obat jadi

4. Ruang pendingin (Cold Room): $2^{\circ} \mathrm{C}-8^{\circ} \mathrm{C}$ adalah tempat penyimpanan material dan produk yang disimpan dalam rentang suhu tersebut

Kendaraan dan Perlengkapan

Industri Farmasi yang diteliti tidak menggunakan kendaraan dan perlengkapan pribadi untuk pengiriman obat dimana di CPOB dijelaskan bahwa industri farmasi diusahakan untuk memiliki dan menggunakan kendaraan serta perlengkapan industri sendiri untuk menangani obat. 
Hal tersebut terjadi karena pada awalnya Industri Farmasi tersebut menggunakan kendaraan perlengkapan sendiri, akan tetapi biaya yang dikeluarkan lebih banyak sehingga tidak menggunakan cara tersebut dan memilih menggunakan jasa pihak ke 3.

Menggunakan jasa pihak ke 3 masih diperbolehkan asalkan mutu obat selalu terjaga selama pengiriman ke kustomer serta risiko penyimpangan harus diminimalisir sedemikian rupa dan selalu dilakukan pemeliharaan agar terhindar dari efek yang dapat menurunkan kualitas obat yang didistribusikan².

Jasa pihak ke 3 yang digunakan oleh pihak Industri Farmasi tersebut, selalu dipantau kondisi penyimpanan seperti suhu dan kelembaban setiap saat dan terkalibrasi serta dilakukan validasi pengiriman agar terjamin barang yang dikirim sampai ke kustomer dengan mutu yang masih baik. Kendaraan yang digunakan disesuaikan dengan volume pengiriman sehingga kapasitas selalu memadai².

Wadah Pengiriman dan Pelabelan

Wadah pengiriman yang digunakan pada Industri Farmasi tersebut tidak boleh memberikan efek yang dapat menurunkan kualitas obat dan dapat melindungi dari pengaruh eksternal. Apabila wadah pengiriman rusak atau pecah, Industri Farmasi tersebut telah memiliki prosedur untuk menangani hal tersebut dan segera dibuat berita acara dan diberikan bukti dengan foto sebelum pengiriman bahwa produk yang sebelumnya dikirim memiliki wadah yang masih baik sehingga bukan tanggung jawab Industri Farmasi tersebut².

\section{Pengiriman}

Industri Farmasi akan melakukan pengiriman produk hanya ketika menerima pesanan dari kustomer atau adanya produk kembalian yang akan dikirim gantinya secara resmi. Apabila tidak ada pesanan atau produk kembalian tersebut tidak memnuhi kriteria untuk dikirimkan penggantinya maka pengiriman tidak akan diproses. Setiap pengiriman dibuat catatan secara tertulis atau elektronik yang dapat menjamin ketertelusuran produk pada saat pengiriman. Produk yang kedaluwarsa tidak akan terkirim atau diproses oleh sistem karena akan langsung diblok ketika ED produk di bawah 6 bulan sehingga tidak akan terkirim produk kedaluwarsa oleh Industri Farmasi.

\section{Dokumentasi}

Industri Farmasi tersebut sudah memiliki prosedur dokumentasi yang baik sesuai dengan $\mathrm{CPOB}$. Setiap dokumentasi pada Industri Farmasi tersebut manual ataupun elektronik dapat ditelusuri setiap saat serta memiliki backup data agar dapat mencegah kehilangan data. Kondisi penyimpanan tiap produk dicatat dengan baik secara permanen baik tertulis maupuk elektronik ${ }^{2}$. 


\section{Keluhan}

Semua keluhan terkait mutu obat seperti kerusakan atau pemalsuan obat dikaji bersama terlebih dahulu sesuai bidang terkait untuk keputusan yang akan diambil seperti penarikan produk. Produk yang telah ditarik akan di pisahkan diruang karantia dan diberi label ${ }^{2}$.

\section{Kegiatan Kontrak}

Kegiatan pengiriman pada Industri Farmasi tersebut tidak menggunakan kendaran pribadi untuk mengirimkan pada distributor sehingga melakukan kerja sama. Kerja sama yang dilakukan kepada sarana lain tersebut telah dilakukan dengan kontrak tertulis yang telah disetujui dimana pada kontrak tersebut sudah termasuk tanggung jawab masing masing pihak. Penerima kontrak dilakukan audit pada awal kerja sama dan dilakukan audit secara berkala tiap tahun ${ }^{2,15}$.

\section{Pemetaan Proses Pergudangan}

Warehouse (gudang) merupakan bagian sistem logistik pada industri yang berfungsi untuk menyimpan produk dan menyediakan informasi status serta kondisi bahan bahan yang tersedia di gudang ${ }^{18}$. Gudang adalah area yang memfasilitasi proses dan aktivitas pengelolaan produk. Berikut fungsi utama gudang yaitu ${ }^{19}$ :

1. Penerimaan yaitu menerima pesanan bahan awal atau pengemas dari pemasok dengan menyesuaikan dengan pesanan industri, kemudian menjamin kualitas bahan yang diterima, serta mendistribusikan ke area produksi.

2. Penyimpanan yaitu penyimpanan produk yang diterima ditempat yang telah disesuaikan kriteria penyimpanan sebelum ada permintaan produk tersebut.

3. Pengambilan pesanan yaitu pengambilan produk dari penyimpanan di gudang sesuai pesanan dan kebutuhan.

4. Pengemasan yaitu pengemasan atau pengepakan beberapa produk yang akan dikirimkan sesuai pesanan dan kebutuhan.

5. Penyortiran dan pengiriman yaitu pesanan yang diambil dipecah sesuai pesanan individu, kemudian dilakukan pemeriksaan pada kontainer atau armada hingga pengiriman.

Pemetaan proses pergudangan merupakan proses mapping atau pemetaan secara visual pada tiap fisik barang dan informasi yang didapatkan dari sistem yang digunakan sampai ke pihak distributor atau pembeli dengan disertai lead time pada tiap proses. Fungsi dari mapping yaitu untuk mengidentifikasi pada proses mana terjadinya pemborosan sehingga dapat dilakukan evaluasi untuk meminimalisir pemborosan tersebut. Pemborosan (waste) mempunyai 7 klasifikasi yang disebut dengan TIMWOOD (Transportation, Inventory, Movement, Waiting, Overproduction, Over Processing, Defects) yang diantaranya sebagai berikut ${ }^{20}$ : 
1. Over Production: Ketika Industri Farmasi memproduksi produknya lebih banyak dari permintaan konsumen.

2. Defects: Terdapat produk yang cacat saat melakukan proses produksi atau saat sudah menjadi produk jadi.

3. Unnecessary Inventories: Terjadi saat flow proses terdapat material atau persediaan produk yang berlebih.

4. Inappropriate Processing: Terdapat flow proses yang tidak memberikan nilai tambah dan berlebihan sehingga membuang waktu.

5. Excessive Transportation: Terjadinya pemborosan ketika melakukan pemindahan material bahan baku atau produk jadi pada setiap proses yang dapat mengakibatkan bertambahnya waktu yang dibutuhkan untuk menangani material tersebut.

6. Waiting: Terjadi ketika melakukan proses yang membuang waktu tanpa menghasilkan nilai tambah seperti menunggu orang, barang, ataupun informasi untuk menunggu proses selanjutnya.

7. Unnecesarry Movement: Adanya gerakan tidak perlu dan tidak memberikan nilai tambah yang dilakukan seperti pergerakan dari pekerja ataupun material.

Pemetaan dari proses pergudangan pada salah satu Industri Farmasi di Jakarta dapat dilihat pada gambar dibawah:

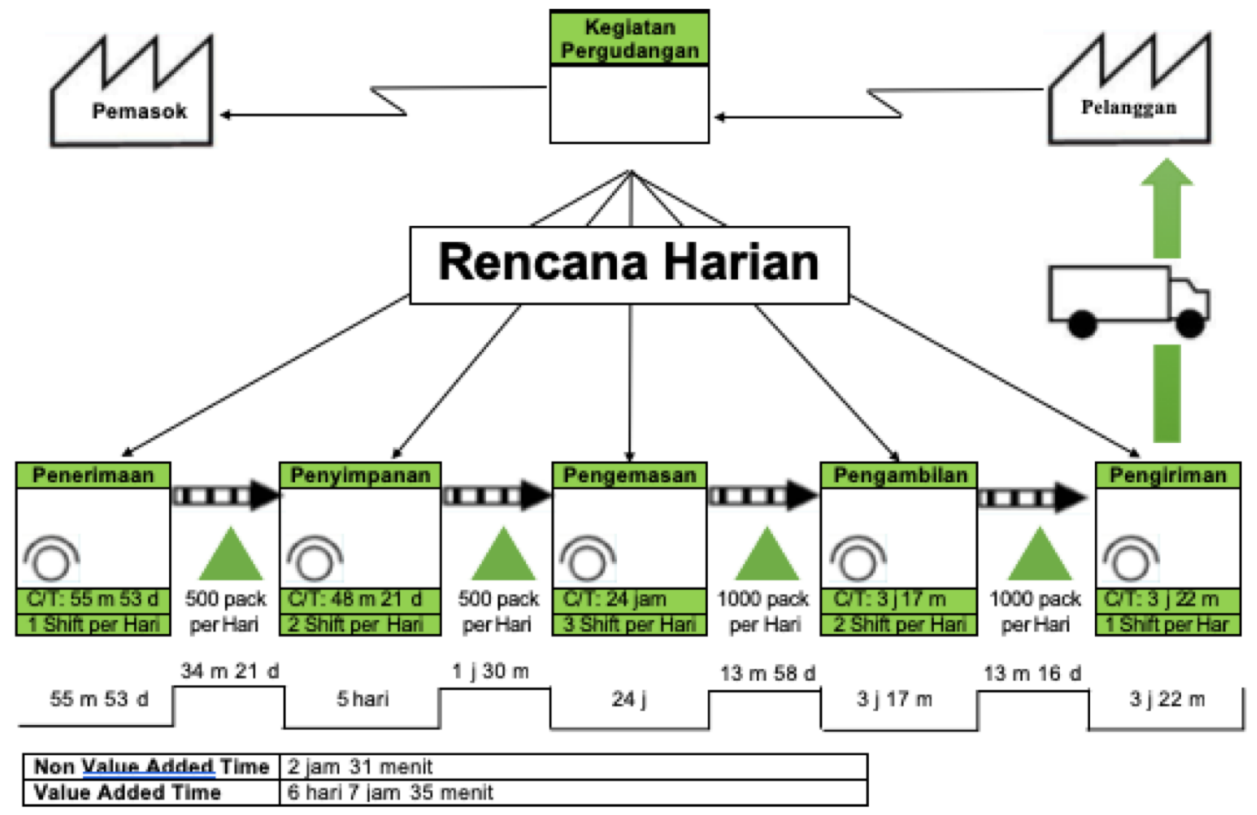

Gambar 1. Pemetaan Proses Pergudangan ${ }^{3}$

Dari pemetaan pada Gambar 1 dapat dilihat bahwa dari semua proses yang dilakukan di warehouse, proses mana dan berapa lama waktu pada tiap proses sehingga bisa dilihat terjadi pemborosan. Hasil analisis menunjukkan adanya beberapa hal yang dapat menyebabkan pemborosan (waste) pada warehouse Industri Farmasi tersebut yaitu:

Over Production: Setelah dilakukan pengamatan dan diskusi/wawancara dengan pihak-pihak terkait maka waste over production ada pada kelebihan produksi produk. 
Hal ini dibuktikan dengan jumlah produksi yang melebihi permintaan. Sehingga perlunya perencanaan pembelian yang lebih akurat dan terjadwal dengan baik.

Unnecessary Inventory: Pada Industri Farmasi terjadi over production pada saat pemesanan material dan produksi obat jadi. Akibatnya dapat meningkatkan barang pasif dan menjadi penumpukan produk pada gudang serta hal tersebut akan mengurangi kapasitas gudang. Untuk mengatasinya, perlu dilakukan perencanaan pembelian yang lebih akurat dan terjadwal dengan baik.

Inappropriate processing: Setiap penyimpanan baik material atau obat jadi di gudang harus pada rak yang disediakan, namun ketentuan ini belum diterapkan karena adanya over production yang menyebabkan kurangnya kapasitas gudang dan penyimpanan produk tidak sesuai tempatnya. Selain itu, hal tersebut akan mengakibatkan ketercampur bauran produk yang dapat menyebabkan penambahan proses dalam pemindahan produk. Untuk mengatasinya, perlu dilakukan perencanaan pembelian yang lebih akurat dan terjadwal dengan baik serta menambah kapasitas gudangan dengan membuka gudang baru atau menitipkan pada Industri lain dengan penyewaan gudang.

Execessive transportation: Setiap hari Industri Farmasi memproduksi produk jadi hingga 300 - 500 pack dan kemudian disimpan pada area penyimpanan, dan mengirim atau menyalurkan produk tersebut sekitar 500 - 1000 pack produk setiap hari yang diangkut oleh karyawan ke armada pengiriman. Hal tersebut dapat memberikan dampak pada karyawan berupa kelelahan ataupun cidera sehingga kerja karyawan tidak optimal. Untuk mengatasi hal tersebut, perlu penambahan tenaga kerja sehingga mengurangi beban.

Waiting: Adanya keterlambatan dalam pengecekan produk yang akan dikirim sehingga armada yang datang menunggu lama. Selain itu, terjadi keterlambatan datangnya material dari gudang atau pemasok sehingga memaksa jadwal produksi berubah dan menambah leadtime proses. Lalu adanya kesalahan pada saat pengecekan barang membuat proses serah terima barang akan membutuhkan waktu yang lama. Perlu dilakukan pengecekan sebelum datangnya armada sehingga barang siap untuk di masukkan kedalam armada dan perlu penegasan kembali kepada supplier agar tidak terjadinya keterlambatan pengiriman.

Execessive movement: Setiap hari petugas gudang melakukan penyimpanan dan pengambilan sekitar 100 - 200 pack obat secara manual dengan menggunakan forklift. Hal tersebut dapat memberikan dampak pada karyawan berupa menurunnya kinerja karyawan dan dapat merugikan kondisi kesehatan karyawan karena melakukan aktivitas berulang-ulang sehingga menjadi tidak optimal. Untuk mengatasi hal tersebut, perlu penambahan tenaga kerja sehingga mengurangi beban. 


\section{Kesimpulan}

Kegiatan pergudangan pada salah satu gudang Industri Farmasi di Jakarta sudah memenuhi ketentuan CPOB 2018 Bab VI pada aspek personalia, organisasi dan manajemen, manajemen mutu, penerimaan, dokumentasi, keluhan, produk kembalian, dan kegiatan kontrak. Namun masih ada yang perlu diperbaiki pada bagian aspek area penyimpanan. Hal ini akan berdampak pada kondisi mutu produk sehingga harus selalu dijaga agar tidak terjadi penurunan kualitas. Selain itu masih terdapat pemborosan yang mengakibatkan kurang optimalnya proses pergudangan pada Industri Farmasi tersebut. Sehingga untuk memperbaiki kekurangan tersebut, hendaknya diterapkan langkah-langkah atau perbaikan hasil CAPA pada sistem operasional di Industri Farmasi tersebut.

\section{Daftar Pustaka}

1. MENKES RI. Industri Farmasi. Jakarta: Menteri Kesehatan Republik Indonesia; 2010.

2. BPOM RI. Pedoman Cara Pembuatan Obat yang Baik. Jakarta: Badan Pengawas Obat dan Makanan Republik Indonesia; 2018.

3. Widyarto, A. Peran Supply Chain Management dalam Sistem Produksi dan Operasi Perusahaan. Benefit, 2012; 16(2): 91-98.

4. Satibi, Fudholi, A., Tuko, EC., Swastiandari, GL. Pengendalian Persediaan, Fasilitas Penyimpanan dan Distribusi pada Industri Farmasi dalam Mendukung Ketersediaan Obat Era JKN. JMPV, 2019; 9(1): 27-37.

5. Musfiroh, F. Penerapan Lean Warehouse Pada Gudang Produk Jadi Untuk Meminimasi Pemborosan. Surakarta: Universitas Muhammadiyah Surakarta; 2017.

6. Ramaa, A. Subramanya, KN., Rangaswamy, TM. Impact of Warehouse Management System in a Supply Chain. IJCA. 2012; 54(1): 14-20.

7. Felix, TS., Chan, HK. Improving the productivity of order picking of a manual-pick and multi-level rack distribution warehouse through the implementation of class-based storage. Expert Systems with Applications, 2011; 38(3): 2686-2700

8. Shafaat, K., Hussain, A., Kumar, B., Hasan R., Prabhat PKV. An overview: storage of pharmaceutical products. J Pharm Pharm Sci, 2013; 2(5): 2499-2515.

9. Purnama, RI., Ikatrinasari, ZF. Perbaikan Sistem Produksi Minyak Angin Aromatherapy Melalui Lean Manufacturing Di PT. Us, Jawa Barat. J@TI Undip, 2013; 8(2): 99-106.

10. Dewi, SK. Analisis Waste Pada Proses Produksi Dengan Lean Production. Sentra, 2018; 3: 100-105.

11. Lewis, NA. Tracking for Lean Solid-Dose Manufacturing, Pharmaceutical Technology. ABI/INFORM Research, 2006; 30(10). 
12. Mrugalska, B., Wrywicka, M. Barriers to Eliminating Waste in Production System. Proceeding of the 6th International Conference On Engineering, Project and Production Management; 2015.

13. Mrugalska, B., Wrywicka, M. Toward Lean Production in Industry 4.0, Proceeding of the 7th International Conference on Engineering, Project and Production Management; 2017.

14. Harsono, AR., Arijanto, S., Azlin, F. Usulan Perbaikan untuk Pengurangan Waste pada Proses Produksi dengan Metode Lean Manufacturing. Proceeding Seminar Nasional IV Manajemen dan Rekayasa; 2010

15. BPOM RI. Petunjuk Operasional Penerapan Pedoman Cara Pembuatan Obat Yang Baik 2012 Jilid II. Jakarta: Badan Pengawas Obat dan Makanan Republik Indonesia; 2014.

16. Kapoor, D. Vyas, RB., Dadarwal, D. An Overview on Pharmaceutical Supply Chain: A Next Step towards Good Manufacturing Practice. Drug Des Int Prop Int J. 2018; 1(2): 49-54.

17. BPOM RI. Petunjuk Operasional Penerapan Pedoman Cara Pembuatan Obat Yang Baik 2012 Jilid I. Jakarta: Badan Pengawas Obat dan Makanan Republik Indonesia; 2013.

18. Zaroni. Manajemen Risiko Rantai Pasok dalam Model SCOR [diunduh 9 Mei 2020]. Tersedia dari: http://supplychainindonesia.com/new/-manajemen-rantai-pasok-dalam-modelscor/.

19. Hadiguna, RA. Setiawan, H. Tata Letak Pabrik. Yogyakarta: Andi; 2008.

20. Hines, P., Taylor, D. Going Lean. USA: Lean Enterprises Research Center Cardiff Business School; 2000. 